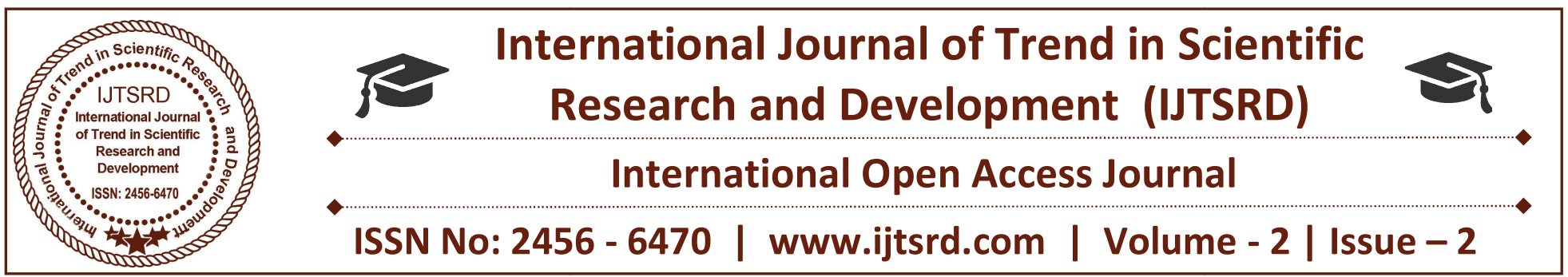

\title{
Seismic Analysis of Multi Storied Building in Different Zones
}

\author{
Brajesh Kumar Tondon \\ Student, Civil Engineering, Saveetha School of \\ Engineering, Saveetha University, \\ Chennai, Tamil Nadu, India
}

\author{
Dr. S. Needhidasan \\ Associate Professor, Civil Engineering, Saveetha \\ School of Engineering, Saveetha University, \\ Chennai, Tamil Nadu, India
}

\section{ABSTRACT}

Construction of building requires proper planning and management. Building are subjected to various loads such as dead load, live load,wind load and seismic load .seismic load has extreme adverse effect on building so it is necessary to perform seismic analysis. This paper describe about the response of building when it is subjected to seismic load, this response can be shown by story drift and base shear .seismic analysis has been performed on $(\mathrm{G}+8)$ building which is located in zone $2 \& 4$ using STAAD Pro software . Analysis has been performed according to IS 1893 PART 1 (2002).

Keywords: seismic, response spectrum, story drift, base shear

\section{INTRODUCTION}

Earthquake is a natural calamity which cause huge loss of life as well as property, many people becomes homeless, children lost their parents, women become widow, affects the economy of a country very adversely. It takes many years to recover and compensate the loss caused due to earthquake. Tremors of earthquake can be realized from very far distance from its occurring place.

Earthquake is one of the most devastating natural calamity in which earth surface shakes due to release of seismic energy from crust along fault. Earthquake has adverse effect on the building. Seismic waves are generated from crust and travelled toward earth surface, seismic waves are measured using
Seismograph and Richter scale .when seismic waves are subjected on building the base of building starts shaking and eventually gets collapse. Seismic analysis is performed to understand response of building when subjected to earthquake. Construction of multi-storied buildings has become inevitable both for residential and as well as office purposes. The high raised structures are not properly designed for the resistance of lateral forces. It may cause to the complete failure of the structures. The earthquake resistance structures are designed based on some factors. The factors are natural frequency of the structure, damping factor, type of foundation, importance of the building and ductility of the structure.

In this paper seismic analysis of $\mathrm{G}+8$ BUILDING which lies in zone2\& 4 has been described and response of building is shown in the form of story drift and base shear. The analysis has been done using STAAD Pro according to IS 1893 CODE for seismic parameter and designing is done using AutoCAD.

\subsection{OBJECTIVE OF THE PROJECT}

- To perform seismic analysis on building in different zones.

- To analyze the effect of various load imposed on building.

- To ensure safety of building from seismic wave in various zones.

- To observe the impact of earthquake on building. 
- To obtain the result of base shear, story drift and movement of building.

\subsection{METHODS OF ANALYSIS}

\section{a) Equivalent static analysis}

It is one of the methods for calculating the seismic loads. In practical as it does not take into account all the factors that are the importance of the foundation condition. The equivalent static analysis is used to design only for the small structures. In this method only one mode is considered for each direction. The earthquake resistant designing for the low rise structures the equivalent static method is enough. It assumes that building acts in its fundamental mode.

\section{b) Response spectrum analysis}

This approach permits the multiplier modes of response of a building to be taken into account. Computer analysis can be used to determine these modes for a structure.

This method takes into account all the five important engineering properties of the structures.

i. Fundamental natural period of vibration of the building ( $\mathrm{T}$ in seconds).

ii. The damping properties of the structure.

iii. Type of foundation provided for the building.

iv. Importance factor of the building.

\subsection{SEISMIC PARAMETER}

- Zone factor

$$
: 0.1
$$

- Damping ratio

: 0.05

- Importance factor : 1

- Time of vibration in both xand $\mathrm{z}$ axis : 0.05

\subsection{LIST OF SOFTWARES USED}

- AUTO CADD

- STAAD PRO

\section{ANALYSIS OF $\mathbf{G}+8$ BUILDING IN DIFFERENT SEISMIC ZONES}

Earthquake is a natural calamity which we cannot control, its beyond our control, so to prevent the damage caused due to earthquake we should analyze the building by applying seismic load and analyze the effect caused due to it and after analyzing seismically we should take some measure or bring some changes in methods to ensure safety to the building. Seismic analysis of a building has been explained using STAAD PRO.

Plan of building is drawn in auto cad then center line diagram of the structure has transported to Staad pro fixed supports has been provided and various loads such as dead load, live load, wind load etc. which is vital for the analysis of the structure has been provided and some design load combinations has also been provided according to IS CODE 1893. After assigning loads we should define property of the material according to IS CODE. We have to specify column and beam size, reinforcement, grades of concrete etc.

We have to define seismic properties of particular zone according to which structure respond, in my case zone of analysis in zone 2.some of the seismic parameter are mentioned below

\subsection{GENERAL STATEMENT OF BUILDING}

$\begin{array}{llc}\text { Ground floor }: & 3 \mathrm{~m} \\ \text { Floor to floor height } & : & 3 \mathrm{~m} \\ \text { Height of plinth : } & 0.6 \mathrm{~m} \\ \text { Depth of foundation }: & 2 \mathrm{~m} \\ \text { Materials } \quad: & \text { Concrete } \\ \text { Concrete grade : } & \text { M25 } \\ \text { All steel grade : } & \text { FE } 415\end{array}$




\subsection{SEISMIC ANALYSIS RESULT IN ZONE $2 \&$ 4}

Seismic analysis of a $\mathrm{G}+8$ building has been performed by equivalent static method and response spectrum analysis seismic analysis has been done according to IS 1893-2002 result of the analysis has been shown below:

\section{- Design of beam and column}

Beams are designed for flexure, shear and torsion. If required the effect of the axial force may be taken into consideration. For design to be performed as per IS: 13920 the width of the member shall not be less than $200 \mathrm{~mm}$.Also the member shall preferably have a width-to depth ratio of more than 0.3 .

\section{BEAM \& COLUMN DIMENSION}

COLUMN: $0.8 \mathrm{~m} * 0.3 \mathrm{~m}$ BEAM: $0.5 \mathrm{~m} * 0.3 \mathrm{~m}$ BEAM: $0.3 * 0.23 \mathrm{~m}$

B E A M N O. 1357 DES I G N R E S U L T S

M25 Fe 415 (Main) Fe415 (Sec.)

LENGTH: $8880.0 \mathrm{~mm}$ SIZE: $300.0 \mathrm{~mm}$ X $500.0 \mathrm{~mm}$ COVER: $25.0 \mathrm{~mm}$

SUMMARY OF REINFORCED. AREA (Sq.mm)

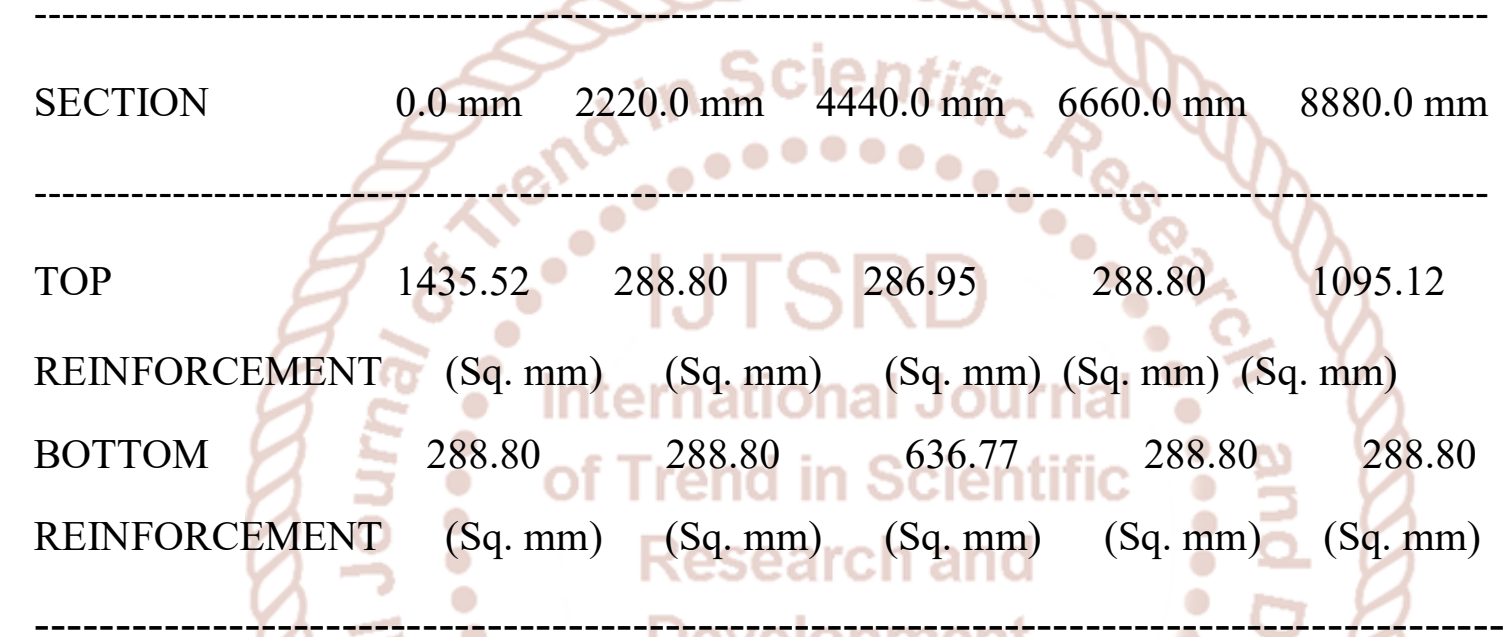

\section{- Equivalent analysis in zone $2 \& 4$}

TOTAL APPLIED LOAD (KN METE) SUMMARY (LOADING 2) SUMMATION FORCE-X $=1367.12$ SUMMATION FORCE-Y $=0.0 \quad$ SUMMATION FORCE- $Z=0.00$ SUMMATION OF MOMENTS AROUND THE ORIGIN-

\section{ZONE 2}

\begin{tabular}{|l|l|}
\hline $\begin{array}{l}\text { MAXIMUM } \\
\text { DISPLACEMIENTS }\end{array}$ & AT NODE \\
\hline $\mathrm{X}=-1.00309 \mathrm{E}+00$ & 553 \\
\hline $\mathrm{Y}=-5.98345 \mathrm{E}-01$ & 544 \\
\hline $\mathrm{Z}=8.09371 \mathrm{E}+00$ & 524 \\
\hline $\mathrm{RX}=2.94012 \mathrm{E}-03$ & 529 \\
\hline $\mathrm{RY}=-2.90243 \mathrm{E}-03$ & 462 \\
\hline $\mathrm{RZ}=1.53528 \mathrm{E}-03$ & 940 \\
\hline
\end{tabular}

Table 1.1

\section{ZONE 4}

\begin{tabular}{|c|c|}
\hline $\begin{array}{c}\text { MAXIMUM } \\
\text { DISPLACEMIENTS }\end{array}$ & AT NODE \\
\hline $\mathrm{X}=9.39709 \mathrm{E}-01$ & 515 \\
\hline $\mathrm{Y}=-6.20151 \mathrm{E}-02$ & 468 \\
\hline $\mathrm{Z}=1.45758 \mathrm{E}-01$ & 376 \\
\hline $\mathrm{RX}=1.09649 \mathrm{E}-04$ & 526 \\
\hline $\mathrm{RY}=3.44694 \mathrm{E}-04$ & 377 \\
\hline $\mathrm{RZ}=-3.78270 \mathrm{E}-04$ & 279 \\
\hline
\end{tabular}

Table 1.2 
STATIC LOAD/REACTION/ EQUILIBRIUM SUMMARY FOR CASE NO. 4 LOADTYPE SEISMIC TITLE EQ +Z CENTER OF FORCE BASED ON Z FORCES ONLY (METE). (FORCES IN NON-GLOBAL DIRECTIONS WILL INVALIDATE RESULTS)

$X=0.111121535 E+02 \quad Y=0.204968772 E+02 \quad Z=0.862694467 E+01$

TOTAL APPLIED LOAD (KN METE) SUMMARY (LOADING 4) SUMMATIONFORCE-X $=0.00$ SUMMATION FORCE- $Y=0.00 \quad$ SUMMATION FORCE-Z $=1367.12$

SUMMATION OF MOMENTS AROUND THE ORIGIN-

$\mathrm{MX}=28021.66 \quad \mathrm{MY}=-15191.63 \quad \mathrm{MZ}=0.0$

\section{- RESPONSE SPECTRUM ANALYSIS OF BUILDING}

After conducting the equivalent seismic analysis it has been analyzed using response spectrum analysis, building has been tested on the basis of peak shear story drift, modal frequency and results obtained is described below through different parameters.

ZONE 2

\begin{tabular}{|c|c|c|c|}
\hline $\begin{array}{c}\text { STORE } \\
\text { Y }\end{array}$ & $\begin{array}{c}\text { LEVEL } \\
\text { IN } \\
\text { MIETER }\end{array}$ & $\begin{array}{c}\text { PEAK } \\
\text { STORY } \\
\mathbf{X}\end{array}$ & $\begin{array}{c}\text { SHEAR } \\
\text { IN KN } \\
\mathbf{Z}\end{array}$ \\
\hline 8 & 21 & 37512.27 & 312824.91 \\
\hline 7 & 18 & 48198.91 & 40768.17 \\
\hline 6 & 15 & 57337.94 & 48461.46 \\
\hline 5 & 12 & 64787.22 & 54827.33 \\
\hline 4 & 9 & 70458.41 & 59814.19 \\
\hline 3 & 6 & 74330.25 & 63389.78 \\
\hline 2 & 3 & 76400.84 & 65485.98 \\
\hline 1 & 0 & 76930.96 & 66164.39 \\
\hline 0 & 0 & 76930.96 & 66164.39 \\
\hline
\end{tabular}

\section{ZONE 4}

\begin{tabular}{|c|c|c|c|}
\hline $\begin{array}{c}\text { STORE } \\
\mathbf{Y}\end{array}$ & $\begin{array}{c}\text { LEVEL } \\
\text { IN } \\
\text { MIETRE }\end{array}$ & $\begin{array}{c}\text { PEAK } \\
\text { STORY } \\
\text { SHEAR }\end{array}$ & $\begin{array}{c}\text { SHIEAR } \\
\text { IN KN } \\
\mathbf{Z}\end{array}$ \\
\hline 8 & 21 & 14000.97 & 14545.21 \\
\hline 7 & 18 & 17675.94 & 18367.21 \\
\hline 6 & 15 & 20803.46 & 21646.46 \\
\hline 5 & 12 & 23339.57 & 24355.25 \\
\hline $0=0$ & 9 & 25258.45 & 26474.51 \\
\hline 3 & 6 & 26556.20 & 27995.09 \\
\hline 2 & 3 & 27260.38 & 28912.06 \\
\hline 1 & 0 & 27441.23 & 29216.55 \\
\hline 0 & 0 & 27441.23 & 29216.55 \\
\hline & & & \\
\hline
\end{tabular}

Table 1.3

\section{FORCE AND MOMENT IN VARIOUS MODES}

\begin{tabular}{|c|c|c|c|c|c|c|c|}
\hline MODE & PERIOD & $\mathrm{F}_{\mathbf{X}}$ & $\mathrm{F}_{\mathbf{Y}}$ & $\mathrm{F}_{\mathbf{Z}}$ & $\mathbf{M}_{\mathbf{X}}$ & $\mathbf{M}_{\mathbf{Y}}$ & $\mathbf{M}_{\mathbf{Z}}$ \\
\hline 1 & 1.679 & -3.96 & -20.76 & 6091.77 & 1092.78 & -7340.5 & -160.99 \\
\hline 2 & 1.643 & 17.33 & 0.00 & 5.86 & 107.26 & 1259.45 & -305.94 \\
\hline 3 & 1.300 & 7367.24 & 0.64 & 0.91 & 11.77 & 5414.4 & -28214 \\
\hline 4 & 1.025 & 1282.48 & -126.69 & -227.27 & -3275.1 & 1364.95 & -5274.2 \\
\hline 5 & 1.024 & 7421.23 & 153.19 & 274.58 & 3955.92 & 64213.46 & -13799 \\
\hline 6 & 0.794 & 13.02 & -18.68 & 2090.08 & 38349.30 & 23445.38 & -459.34 \\
\hline
\end{tabular}

Table 1.4 
International Journal of Trend in Scientific Research and Development (IJTSRD) ISSN: 2456-6470 CALCULATED FREQUENCIES FOR SEISMIC LOAD

\begin{tabular}{|c|c|c|c|}
\hline MODE & FREQUENCY(CYCLES/SEC) & PERIOD(SEC) & ACCURACY \\
\hline 1 & 0.596 & 1.67854 & $5.198 \mathrm{E}-15$ \\
\hline 2 & 0.609 & 1.64317 & $9.355 \mathrm{E}-14$ \\
\hline 3 & 0.769 & 1.29983 & $2.597 \mathrm{E}-11$ \\
\hline 4 & 0.975 & 1.02533 & $6.139 \mathrm{E}-10$ \\
\hline 5 & 0.977 & 1.02382 & $1.892 \mathrm{E}-10$ \\
\hline 6 & 1.259 & 0.799440 & $3.851 \mathrm{E}-08$ \\
\hline
\end{tabular}

Table 1.5

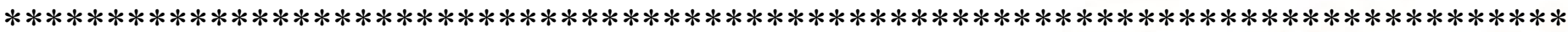

TIME PERIOD FOR X 1893 LOADING $=0.50000$ SEC $* *$ SA/G PER 1893=2.500, LOAD FACTOR $=1.000 \quad$ FACTOR $\checkmark \mathrm{V}$ PER $1893=0.0250 \quad \mathrm{X} \quad 42763.89$ TIME PERIOD FOR Z 1893 LOADING $=0.50000$ SEC SA/G PER 1893=2.500, LOAD FACTOR=1.000 FACTOR V PER $1893=0.0250 \times 42763.89$

\section{RESULTS \& CONCLUSION}

In this project seismic response of a residential $\mathrm{G}+8$ $\mathrm{RC}$ frame building is analyzed by the linear analysis approaches of Equivalent static lateral force and Response spectrum methods using Staad Pro 2016 software as per the IS- 1893-2002-Part-1. These analysis are carried out by considering different seismic zones, medium soil type for 1 zones $2 \& 4$ .Different response like lateral force, overturning moment, story drift, displacements, base shear are plotted in order to compare the results of the static and dynamic analysis. Seismic analysis of zone $2 \& 4$ are performed by equivalent static method and response spectrum method and result of seismic analysis in both zones is compared on the basis of story drift, modal frequency, base shear and nodal displacement.

Comparison of result of seismic analysis in zone $2 \& 4$ are described below:

\begin{tabular}{|c|r|r|r|r|}
\hline ZONE & $\begin{array}{l}\text { MAX } \\
\text { PEAK STORY } \\
\end{array}$ & $\begin{array}{l}\text { MIN } \\
\text { INEAK STORY }\end{array}$ & $\begin{array}{l}\text { MAX } \\
\text { SHEAR IN } \\
\text { IN X }\end{array}$ & \multicolumn{1}{l|}{$\begin{array}{l}\text { MIN } \\
\text { SHEAR } \\
\text { IN Z KN Z }\end{array}$} \\
\hline 2 & 76930.96 & 2304.61 & 66164.39 & 1985.29 \\
\hline 4 & 27441.23 & 718.86 & 29216.55 & 783.04 \\
\hline
\end{tabular}

\section{TABLE 1.6}

We will observe that peak story drift will get decrease while moving from ground floor to top floor so it is found that the impact of seismic load is maximum at the ground and subsequently decreases.

1. We found that the value of peak story shear is more in zone 2 than zone 4 it can be seen from above table.

\begin{tabular}{|l|l|l|}
\hline ZONE & $\begin{array}{l}\text { MAX } \\
\text { FREQUENCY }\end{array}$ & $\begin{array}{l}\text { MIN } \\
\text { FREQUENCY }\end{array}$ \\
\hline 2 & 1.259 & 0.596 \\
\hline 4 & 2.739 & 1.359 \\
\hline
\end{tabular}

Table 1.7 
2. We found that that the modal frequency is more at mode 6 and minimum at mode 1, by comparing the modal frequency of zone $2 \& 4$ it is found that the maximum modal frequency of zone 2 is 1.259 while for zone 4 maximum modal frequency is 2.739, so we can understand from table that the by changing the zone factor modal frequency will increase.

3. The base shear, lateral force, story shear, maximum story displacement and overturning moment are increased in both directions as the seismic zone goes from 2 to 4 .

4. The maximum story displacement, overturning moment obtained from response spectrum method is lesser than those obtained by equivalent static lateral force method.

5. Equivalent static lateral force method gives higher values of forces and moments which makes building uneconomical hence consideration of response spectrum method is also needed.

6. Story stiffness is varying in $\mathrm{X}$ - and $\mathrm{Y}$-directions for both methods. Because lateral stiffness of a story is not a stationary property, but an apparent one that depends on lateral load distribution.

\section{REFERENCES}

1. Mahesh.N.Patil, YogeshSonawane "Seismic analysis of multi storied building".volume 4 issue 9 March 2015.

2. Anirudh Gottala, Kintali Sai Nanda Kishore and Dr. ShaikYajdhani "Comparative Study of Static and Dynamic Seismic Analysis of a

3. Multistoried Building" International Journal of Science Technology \& Engineering, Volume 2, Issue 01, July 2015.

4. A.K Chopra "Dynamic of structures theory and Earthquake Engineering" fourth edition, Prentice Hall, 2012.

5. B. Srikanth and V.Ramesh "Comparative Study of Seismic Response for Seismic Coefficient and Response Spectrum Methods", International Journal of Engineering Research and Applications, ISSN: 2248-9622, Vol. 3, Issue 5, Sep-Oct 2013, pp.19191924

6. Gary C. Hart, Kevin Wong "Structural Dynamics for Structural Engineers" John Wiley \& Sons Inc. 2014 7. K.V. Vijayendra "Earthquake resistant design of structures (Subject Code: 06CV834)" Department of Civil Engineering, BIT, Bangalore, VTU Learning.

7. 7.IS 1893: 2002, "Indian Standard Criteria for Earthquake Resistant Design of Structures, Part 1 General provisions and buildings", Bureau of Indian Standards, New Delhi, 2002. 